\title{
Analysis of Diesel Engine Components Durability on Fishing Vessel Fueled with Biodiesel (B30)
}

\author{
Edy Purwanto ${ }^{1}$, Beny Cahyono ${ }^{2}$, Priyonggo Syamrahmadi ${ }^{3}$, Achmad Faisol ${ }^{4}$ \\ (Received: 22 Juni 2021 / Revised: 02 July 2021 / Accepted: 02 July 2021)
}

\begin{abstract}
Indonesian government's policy of using biodiesel as an alternative fuel in the shipping industry is still an intensive discussion. Biodiesel as a substitute for diesel fuel has an impact on engine performance, lifetime and emission. The use of biodiesel fuel will increase the wear rate on metal components in diesel engines. From a series of tests carried out in accordance with Engine Manufacturer Association (EMA) standards, wearing on several engine components would be increase when the engine run using biodiesel palm oil (B30). The results showed that there was $19.8 \%$ aluminum content, $0.75 \%$ iron content, and chromium content in diesel engine lubricating oil with B30 biodiesel fuel higher than using diesel fuel. In addition, the clerance in the pisthon ring also increases and wear is seen on the journal bearing. However, the deposits formation in the diesel engine components made from palm oil biodiesel $\mathrm{B30}$ is $\mathbf{5 . 4 3 \%}$ increase than diesel fuel. From these results, it may be concluded that using of B30 palm oil biodiesel as fuel reduce durability of diesel engine standart.
\end{abstract}

Keywords — biodiesel B30, diesel engine, deposit, engine components, wear.

\section{INTRODUCTION}

$\mathrm{T}$ o reduce dependence on fossil fuels, the Indonesian government since 2016 has implemented the use of biodiesel. Biodiesel as an alternative fuel owing to its advantages over diesel fuel in terms of decreasing emissions and enhancing performance. Biodiesel can have an impact on the power and emissions of diesel engines when used. When comparing diesel fuel to palm oil biodiesel fuel, Hanif [1] found a rise in fuel consumption of $11.93 \%$ to $13.48 \%$, a decrease in thermal efficiency of $2.96 \%$ to $5.33 \%$, and volumetric efficiency that was relatively the same as pure diesel engines. In his study of the usage of biodiesel on a patrol boat, Nurhadi [2] found that utilizing biodiesel instead of high-speed diesel (HSD) fuel resulted in a decrease in load, power, and exhaust temperature of the ship's main motor. When compared to the usage of HSD, however, the use of biodiesel results in an increase in fuel consumption. In their study of the effect of Karanja oil methyl ester on a $780 \mathrm{HP}$ engine, Pandey et al. [3] discovered that the primary brake power was reduced. Yuksek et. al [4] stated that rapeseed biodiesel did not create significant variations in performance results in his study. However, using biodiesel resulted in a $6 \%$ rise in gasoline usage. Using rapeseed biodiesel led to a

Edy Purwanto is with departement of sea operations, Naval Command and Staff College, 12240, South Jakarta, Indonesia, edypurwanto2004@gmail.com

Beny Cahyono is with Departement of Marine Engineering, Institut Teknologi Sepuluh Nopember, Surabaya, 60111, Indonesia. E-mail: benyjtsp98@gmail.com

Achmad Faisol is with departement of science and technology, Naval Command and Staff College, 12240, South Jakarta, Indonesia, faisol_faizah@yahoo.co.id

Priyonggo syamrahmadi is with Center of Research Maritime, Naval Command and Staff College, 12240, South Jakarta, Indonesia, mpriyonggo@yahoo.co.id decrease in caron monoxide (CO) and THC emissions, but (nitrogen oxide) NOx emissions rise significantly.

One of the problems that exist in the use of biodiesel as fuel is the formation of deposits on the engine. The fuel properties of biodiesel are very different from diesel oil. Biodiesel fuel has lower spesific energy, higher density, and viscosity, this condition would be affected on the formation of deposits in the engine. Some material components can form residues accumulated in critical components of internal combustion (IC) engines for instance fuel chambers, piston crowns, intake valves, and exhaust valves. The thickness of the deposit on the cylinder wall is strongly influenced by the temperature of the cylinder wall surface and the area affected by the fuel. The combination of temperature and unburned fuel leads to the large deposit formation in the combustion chamber [5].

Under some conditions, high deposit formation can occur, therefore the appearance of deposits on the engine will considerably aid the development of diesel engine production. The presence of organic molecules such as carbon, hydrogen, oxygen, and nitrogen has been linked to the production of deposits on engine components in several studies. Inorganic elements, such as sulfur and metals, are also present (lead, barium, and calcium). Its structure changes depending on the temperature and place of formation [6].

While showns at low temperatures $\left(<200^{\circ} \mathrm{C}\right)$, wet hydrocarbon components as well as tar-like substance, deposits including black carbon, are apparent. Hydrocarbons and low and high boiling soot make up the majority of the deposit. Nearly dried soot or tar-like compounds can be seen at moderate temperatures (200 to $300^{\circ} \mathrm{C}$ ). The lacquer layer on the deposit reveals that lubricants are the most important factor in deposit development. The color of the deposit looks brighter at high surface temperatures $\left(>300^{\circ} \mathrm{C}\right)$. In this instance, a very thin layer of the deposit is typical [6].

Many investigations have been carried out to see how biodiesel affects the formation of deposits. In their 
study of the consequences of using coconut biodiesel, Arifin et al. [5] found that deposits occur less frequently in coconut biodiesel-fueled engines than in palm oil biodiesel-fueled engines. In their study of the influence of biodiesel on injector deposits, Liaquat et al. [7] found that deposits on the injector of \% Jatropha biodieselfueled engines are drier and more frequent. In his study of the effect of biodiesels on wear and deposit on diesel engine components, Firdaus [8] found that deposits on biodiesel-fueled engine components were more equally distributed and smaller than those on diesel-fueled engine components, as well as less metal wear. Suryantoro et al. [9] found that using biodiesel (B100) raises more deposits than using pure diesel fuel in their study on the influence of biodiesel on deposit formation (B0).

Meanwhile, the effects of biodiesel use also result in different wear rates from the use of diesel fuel. Some research on the use of biodiesel against diesel engine components tear has been conducted. Sinha and Agarwal [10] have examined the effects of B20 use on lubricating oils containing smaller $\mathrm{Fe}, \mathrm{Cr}, \mathrm{Cu}, \mathrm{Zn}, \mathrm{Ni}$, and $\mathrm{Mg}$ metals compared to diesel fuel. While the metal content of $\mathrm{Pb}$ and $\mathrm{Al}$ is greater in the use of biodiesel $\mathrm{B} 20$. Agarwal et. [11] In their research on the effects of biodiesel use stated that the presence of smaller metals $\mathrm{Fe}, \mathrm{Cu}, \mathrm{Zn}, \mathrm{Mg}, \mathrm{Cr}, \mathrm{Pb}$, and $\mathrm{Co}$ in $\mathrm{B} 20$ biodiesel-fueled lubricating oil.

This study discusses the influence of palm oil biodiesel B30 on deposit formation and wear and tear on engine components after use. The method is to research the metal content of lubricating oils and weighing mass deposits in diesel engines that have been running for a long period.

\section{METHOD}

\section{A. Specifications of Palm Oil Biodiesel B30}

The biodiesel fuel used in this research is produced from the palm oil esterification process, with the help of methanol and $\mathrm{KOH}$ catalysts. To determine the fuel properties, laboratory tests were carried out on B30 biodiesel. The test parameters include kinematic viscosity, flash point, density, pour point, and lower heating value. Which is then compared with diesel fuel.

TABLE 1.

FUEL PROPERTIES BIODIESEL B30 PALM OIL

\begin{tabular}{lccc}
\hline Properties & $\begin{array}{c}\text { B30 Palm Oil } \\
\text { Biodiesel }\end{array}$ & $\begin{array}{c}\text { Indonesia Biodiesel } \\
\text { Standard }\end{array}$ & Diesel Fuel \\
\hline Cetane number & 69,8 & Min. 51 & 56,7 \\
Viscosity $\left(40^{\circ} \mathrm{C}\right)[\mathrm{cSt}]$ & 4,43 & $2,3-6,0$ & 2,92 \\
Density $\left[\mathrm{kg} / \mathrm{m}^{3}\right]$ & 856 & $850-890$ & 845,7 \\
Flash Point $\left[{ }^{\circ} \mathrm{C}\right]$ & 96 & Min. 100 & 65 \\
Pour Point $\left[{ }^{\circ} \mathrm{C}\right]$ & -4 & Max. 18 & -3 \\
Low Heating & $45,470.97$ & - & 47054,2 \\
Value $[\mathrm{kJ} / \mathrm{kg}]$ & & & \\
\hline
\end{tabular}

\section{B. Engine Setup}

In this test, lubricating oil is used with specifications as required from the engine manufacture, namely SAE
40. To provide a load in this experiment the engine is connected to a generator, as shown below.

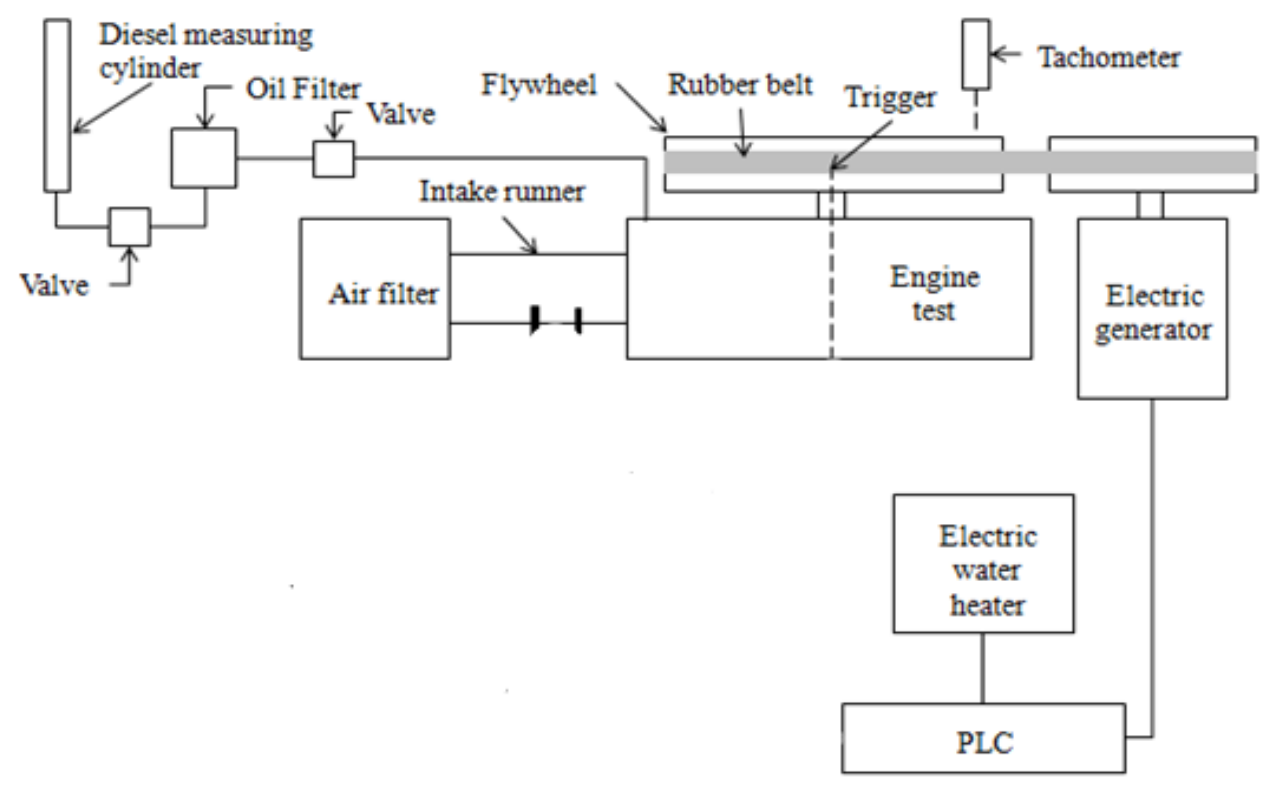

Figure. 1. Engine Set Up. 
Fuel consumption is measured using the method of fuel volume flow per unit time. The volume flow of diesel fuel was reviewed using a measuring tube with a capacity of up to $1000 \mathrm{ml}$.

In order to give optimal results, between testing one another the engine is overhoul and several engine components are replaced with new components, including piston rings, crank pin bearings, injectors. In addition, the engine components that contained deposits were cleaned again and arranged with the same settings. For the specifications of the engine used in this study can be seen in table 2 .

TABEL 2.

ENGINE SPECIFICATION

\begin{tabular}{ll}
\hline Items & Specification \\
\hline Num of Cylinder & 1 \\
Engine Type & Four-stroke, water-cooled \\
Bore x Stroke & $85 \times 87 \mathrm{~mm}$ \\
Piston Displacement & $493 \mathrm{cc}$ \\
Engine Power/rpm & $5.5 \mathrm{~kW} / 2200 \mathrm{RPM}$ \\
Maximum Torque & $3.44 \mathrm{~kg} \cdot \mathrm{m} / 1600 \mathrm{rpm}$ \\
Lubricating Oil Type & $\mathrm{SAE} 40$ \\
Lubricating Oil Capacity & $2.2 \mathrm{~L}$ \\
Compression Ratio & $18: 1$ \\
\hline
\end{tabular}

\section{Experiment}

The diesel engine endurance test was carried out using the method from the Engine Manufacture Association (EMA). The test was completed for 200 hours with variations in rotation and load, including: low idle (30 minutes), high idle (30 minutes), rated power speed (60 minutes), and maximum torque speed (60 minutes). Step by step testing is repeated until the engine operates 200 hours. The load balance can be seen in table 3.

TABEL 3.

VARIATION OF ENGINE SPEED AND LOAD DURING TESTING

\begin{tabular}{lccc}
\hline Step & Engine speed (RPM) & Load (watt) & t (minute) \\
\hline Low idle & 850 & 0 & 30 \\
High idle & 1980 & 750 & 30 \\
Maximum power speed & 2200 & 2500 & 60 \\
Maximum torque speed & 1900 & 3000 & 60 \\
\hline
\end{tabular}

\section{RESULT AND DISCUSSION}

Used lubricant analysis is an effective method to analyze engine condition. From the lubricant analysis, it can be seen the operating conditions of the engine or the condition of the feasibility of the lubricant after or being used. The main function of lubricating oil is to separate two metal surfaces that rub against each other. This function can be realized if the lubricant has the appropriate viscosity. Lubricants that are too thick will not be able to flow into the gaps between the lubricated surfaces and if they are too runny, the lubricant will not be able to separate the two lubricated surfaces.

The high interaction and processes that occur between the engine and the lubricating oil, it is very possible that the lubricating oil is contaminated by various substances resulting from the processes in the engine. The above process can also affect and change the physical and chemical properties of the lubricating oil. There are several pollutants that are commonly found in lubricating oil that has been used in engines. One of them is the presence of metal particles in the lubricating oil. These polluting metals include: Copper $(\mathrm{Cu})$, Iron
(Fe), Chrome (Cr), Aluminum (Al), Tin (Pb), Molybdenum (Mo), Silicon (Si), Sodium (Na) and Magnesium (mg).

The presence of these metals indicates wear on the components of these machines. This wear occurs due to friction between engine components. The level of wear and which components experience wear can be determined based on the type of particles and the concentration of metal particles in the lubricating oil sample used in the engine. So this inspection can provide an opportunity to be able to find out the condition of each engine component, so that if necessary we can take preventive measures to prevent further damage.

From the results of engine testing in the laboratory, it shows that there is an influence from the use of alternative fuels (B30) on the wear of components in diesel engines. From the lubricating oil used for 200 hours, then the chemical properties and physical properties are tested, especially the metal content. To ensure the level of wear, clearen measurements were made on each component and weighed deposit mass on several diesel engine components. 
A. Diesel Engine Component Wear

In addition to iron content, to ensure the level of wear in this study, the levels of aluminum and chromium in the lubricating oil were also measured.

TABLE 4.

METAL CONCENTRATION IN LUBRICATING OIL AFTER TESTING

\begin{tabular}{lccc}
\hline Wear metal content & $\begin{array}{c}\text { Lubricating oil with } \\
\text { palm oil B30 biodiesel } \\
(\mathbf{m g} / \mathbf{l})\end{array}$ & $\begin{array}{c}\text { Lubricating oil with } \\
\text { diesel fuel (mg/l) }\end{array}$ & Method \\
\hline Aluminum (Al) & 7.5 & 6.26 & Flame AAS \\
Iron (Fe) & 1.35 & 1.34 & Flame AAS \\
Chromium (Cr) & $<0.006$ & $<0.006$ & Flame AAS \\
\hline
\end{tabular}

An increase in the content of $19.8 \%$ aluminium and $0.75 \%$ Iron in the lubricating oil with biodiesel fuel (B30) compared to diesel fuel indicates a higher wear and tear when the engine uses biodiesel fuel. In engines, piston rings are usually made of chromium or a metal surface coating. On some cylinder liners are also plated with chrome [12]. In engines, cylinder wall components and crankshaft are the main components that often experience wear and tear in addition to gears, shafts and valves. Changes in fuel with significantly different fuel properties will affect the combustion process in the combustion chember and the character of the engine. Several previous studies have shown an increase in the combustion temperature as evidenced by the high exhaust gas temperature. This condition also affects the performance of the lubricant so that the possibility of friction between components becomes higher, this is also confirmed by measurements of several components, namely road metal, pistons and piston rings in the picture below.

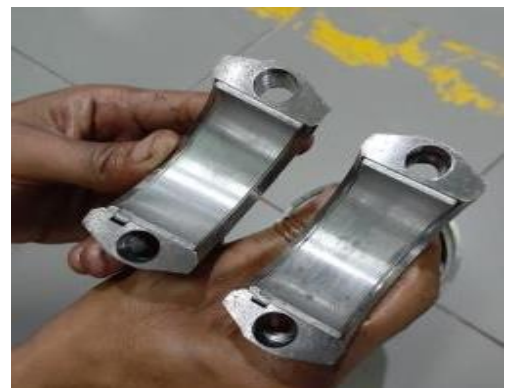

(a)

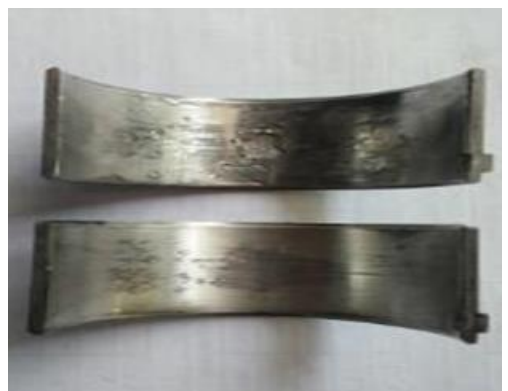

(b)

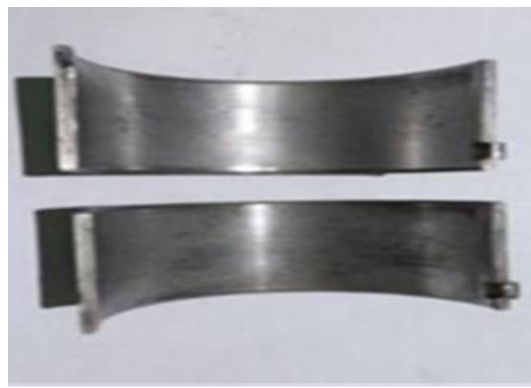

(c)

Figure. 2. An effect of biodisel on metal bearing: standart condition (a), after using biodiesel (b), using diesel fuel (c).

To ensure the level of wear on the engine components, in this study, measurements were made between the crank pin bearing and the road metal. measurements can be seen in table 5. For the engine fueled with biodiesel fuel B30 palm oil, road metal wears higher than the diesel engine with dexlite fuel.

TABLE 5.

GAP ON METAL BEARING

\begin{tabular}{lcc}
\hline Fuel & Gap before testing $(\mathbf{m m})$ & Gap after testing $(\mathbf{m m})$ \\
\hline Diesel oil & 0,05 & 0,05 \\
Palm oil biodiesel B30 & 0,05 & 0,063 \\
\hline
\end{tabular}

\section{B. Deposit on each Component}

The effect of using biodiesel fuel on the deposit of each component can be seen in the table below.

TABLE 6.

\begin{tabular}{lcc} 
MASS OF DEPOSITS ON DIESEL ENGINE COMPONENTS \\
\hline Component & $\begin{array}{c}\text { Mass of Deposit in Engine With } \\
\text { B30 Palm Oil Biodiesel (g) }\end{array}$ & $\begin{array}{c}\text { Mass of Deposit in Engine with } \\
\text { Diesel Fuel (g) }\end{array}$ \\
\hline Piston & 0,24791667 & 0,203472222 \\
Cylinder head & 0,39097222 & 0,467361111 \\
Injector & 0.043 & 0.04 \\
Total & 0,6388 & 0,673611 \\
\hline
\end{tabular}

The use of B30 biodiesel fuel will change the properties of the fuel, such as spesific heat, viscosity, cetane number, and so on. Changes in the nature of the fuel cause the combustion process in the combustion chamber to become a problem, for that it is necessary to change the engine settings. biodiesel fuel, has a higher 
viscosity value than diesel fuel. The value of the viscosity of the fuel will affect the process of fogging the fuel by the injector.

The increase in the viscosity number causes the surface tension of the fuel to increase, so the fuel will be more difficult to atomize. This condition will also affect the shape of the fuel spray. In this work, the spray penetration is defined as maximum distance achieved when injected into stagnant air. is under the injected pressure, the force, the injected physical properties and the resistance pressure on the spray penetration approach. Among these factors, the drag force, which is governed by the magnitude of the relative kinetic energy and aerodynamic drag of the surrounding gas, is very important.
With the same pressure when the fuel is injected through the injector into the combustion chamber, the high viscosity of the fuel causes the penetration of the fuel to be shorter, in addition to the high viscosity causes the fuel droplets to become larger. Fuels with larger droplets make it harder for the fuel to interact with oxygen in the combustion chamber and cause a worse combustion process. So that the combustion process will cause greater soot, this can be seen in table 6, some diesel components have increased where the combustion process is not good, besides that the combustion process is not good can be seen in the picture below, where deposits on the piston ring with biodiesel fuel is higher than diesel.

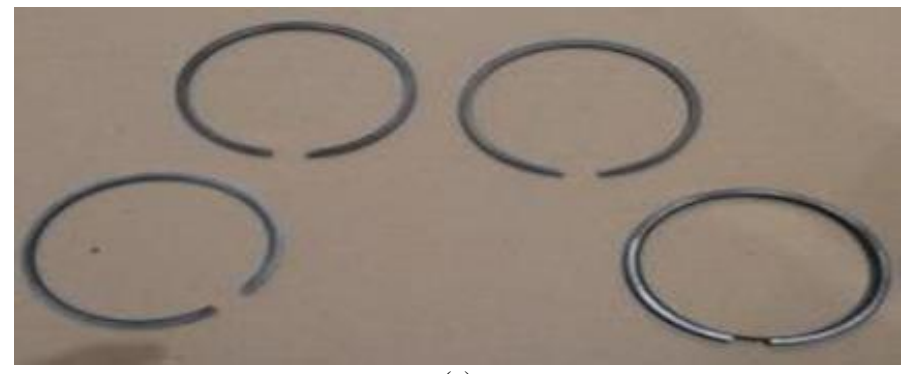

(a)

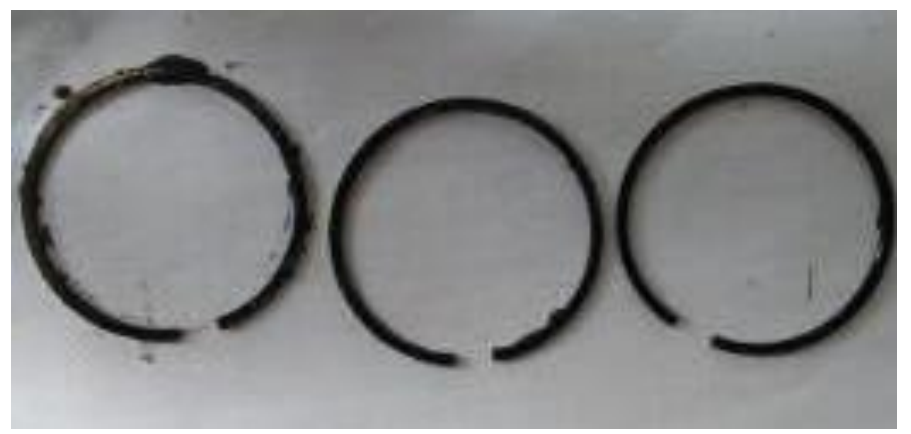

(b)

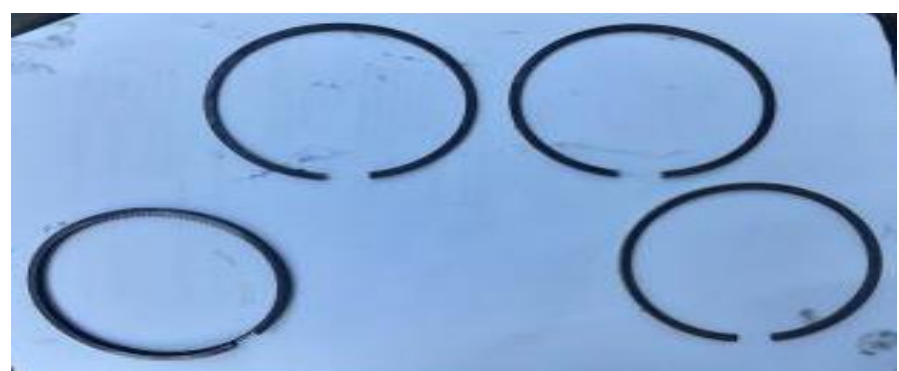

(c)

Figure. 3. The effect of fuel changes on deposits on the piston ring. Component standart (a), after using B30 (b), diesel fuel (c).

In Figure 3, it can be seen visually that there is no significant difference in the presence of deposits on the piston ring due to changes in fuel. This is most likely due to an incomplete combustion process or can also be caused by a high air/fuel rasio (AFR), which is with the composition of the material. richer fuel, the more difficult it is to burn.
The use of biodiesel fuel which is easy to react with other materials allows when the combustion process occurs, the fuel that is not completely burned will react with the metal in the combustion chamber also the lubricating oil that lubricates the piston ring and cylinder liner. the reaction between lubricating oil and fuel causes the quality of the lubricating oil to decrease more quickly. 


\section{CONCLUSION}

This study discusses the durability of diesel engines fueled with biodiesel fuel B30 palm oil and diesel fuel. Diesel engine durability and reability is measured by testing 200 hours on a laboratorium. The results of the comparison of each component after running with several fuels showed a significant change. Using biodiesel B30 palm oil causes greater metal wear in the lubricating oil than the use of Pertamina Dexlite. Palm oil B30 biodiesel fuel causes $19.8 \%$ higher aluminum metal content, $0.75 \%$ higher ferrous metal content, and higher chromium metal content in lubricating oil after being used in diesel engines. In addition, the use of biodiesel B30 palm oil causes a worse condition of the road metal (journal bearing). The above conditions indicate a decrease in engine durability using B30 biodiesel fuel. For this reason, it is necessary to prepare or modify engine components in the use of biodiesel fuel so that the engine is more compatible.

\section{ACKNOWLEDGMENT}

The authors thank the Department of Marine Engineering, Marine Power Plant Laboratory, Pusdiklat Migas for helping the authors in completing their research.

\section{REFERENCES}

[1] Hanif, "Uji Prestasi Motor Diesel Berbahan Bakar Biodiesel Sebagai Bahan Bakar Alternatif," J. R \& B, vol. 4, no.1, Mar 2004.

[2] I.Nurhadi,"Pengaruhpenggunaan Biodiesel Terhadap Performa Dan Komponen Utama Pada Motor Pokok Kri Weling-822.,” P. 98.

[3] A. K. Pandey and M. Nandgaonkar, "Experimental Investigation of the Effect of Esterified Karanja Oil Biodiesel on Lubricating Oil and Wear of a $780 \mathrm{hp} \mathrm{Military} \mathrm{CIDI} \mathrm{Engine,"} \mathrm{SAE} \mathrm{Int.} \mathrm{J.} \mathrm{Fuels}$ Lubr., vol. 3, no. 2, pp. 273-279, May 2010.

[4] L. Yuksek et al, "The Effect and Comparison of Biodiesel-Diesel Fuel on Crankcase Oil, Diesel Engine Performance and Emissions," FME Transactions, vol. 37, no. 2, pp. 91-97, 2009.
[5] Y. Mohamed Arifin and M. Arai, "Deposition characteristics of diesel and bio-diesel fuels," Fuel, vol. 88, no. 11, pp. 2163-2170, Nov. 2009.

[6] G. Lepperhoff and M. Houben, "Mechanisms of Deposit Formation in Internal Combustion Engines and Heat Exchangers," presented at the International Congress \& Exposition, 1993, p. 931032.

[7] A. M. Liaquat et al., "Impact of palm biodiesel blend on injector deposit formation," Appl. Energy, vol. 111, pp. 882-893, Nov. 2013.

[8] A. Firdaus, "Pengujian Ketahanan Motor Diesel Dengan Menggunakan Bahan Bakar Biodiesel," p.93

[9] M. T. Suryantoro et al., "Effect of temperature to diesel (B0) and biodiesel (B100) fuel deposits forming," presented at The 10TH International Meeting Of Advances In Thermofluids (IMAT 2018): Smart City: Advances in Thermofluid Technology in Tropical Urban Development, Bali, Indonesia, 2019, p. 020044.

[10] S. Sinha and A. K. Agarwal, "Experimental Investigations of the Tribological Properties of Lubricating Oil from Biodiesel Fuelled Medium Duty Transportation CIDI Engine," SAE Int. J. Fuels Lubr., vol. 1, no. 1, pp. 719-730, Apr. 2008.

[11] A. K. Agarwal, J. Bijwe, and L. M. Das, "Effect of Biodiesel Utilization of Wear of Vital Parts in Compression Ignition Engine," J. Eng. Gas Turbines Power, vol. 125, no. 2, p. 604, 2003.

[12] J. S. Evans, "Where Does All That Metal Come From?" p. 6.

[13] K. Nantha Gopal and R. Thundil Karuppa Raj, "Effect of pongamia oil methyl ester-diesel blend on lubricating oil degradation of di compression ignition engine," Fuel, vol. 165, pp. 105-114, Feb. 2016.

[14] A. Setiawan and A. Nugroho, "Analisis Korosivitas Biodiesel Yang Diproduksi dari Minyak Goreng Bekas Terhadap Material Baja Karbon," p. 5. 